\title{
GCU
}

Glasgow Caledonian

University

University for the Common Good

\section{Electoral and political changes: the impact on political bureaucratic relationships in Scottish Local Government}

Miller, Karen; McTavish, Duncan

Published in:

Local Government Studies

DOI:

10.1080/03003930.2011.638371

Publication date:

2012

Document Version

Author accepted manuscript

Link to publication in ResearchOnline

Citation for published version (Harvard):

Miller, K \& McTavish, D 2012, 'Electoral and political changes: the impact on political bureaucratic relationships

in Scottish Local Government', Local Government Studies, vol. 38, no. 1, pp. 113-129.

https://doi.org/10.1080/03003930.2011.638371

\section{General rights}

Copyright and moral rights for the publications made accessible in the public portal are retained by the authors and/or other copyright owners and it is a condition of accessing publications that users recognise and abide by the legal requirements associated with these rights.

Take down policy

If you believe that this document breaches copyright please view our takedown policy at https://edshare.gcu.ac.uk/id/eprint/5179 for details of how to contact us. 


\title{
Electoral and Political Changes: the impact on political bureaucratic relationships in Scottish local government
}

\begin{abstract}
This paper explores a fundamental issue in public administration: the political bureaucratic relationship or political administrative interface. Much of the research and writing hitherto has been at central government level; and while important work on local government exists, relatively little exists on local government. The paper makes an important contribution to the field by researching aspects of the political administrative interface in the context of significant electoral and political changes in Scottish local government, which introduced single transferable voting and multi member wards. The research found an increase in intensity of senior bureaucrats' political management roles, a greater bureaucratization of political and policy roles, increased scrutiny yet mixed findings about democratic processes. The approach and findings open up the research field and the paper concludes by suggesting some areas of future research potential.
\end{abstract}

Key words: political-administrative interface; bureaucratization; single transferable vote; multi member wards; local government

\section{Introduction}

The normative political administrative interface in the UK can be traced to the Northcote-Trevelyan recommendations and Carltona doctrine. Over the past decades the UK has experienced numerous political and administrative changes from managerialist reforms (new public management), agencification, to constitutional and electoral reforms including the formation of devolved and differentiated polities. It is within this area that the paper is located, exploring the effects of recent political change on administrative roles. The paper focuses on the reform of the local government electoral system, as introduced in a devolved polity of the UK, Scotland and consequent political changes. Specifically, the paper explores the political administrative interface through analyzing the effects of electoral reform and political change of Scottish local government administration through a series of four propositions.

\section{Literature and Location of Paper}

There have been various scholarly debates and research on the political administrative interface (e.g. Aberbach, Putnam and Rockman, 1981; Aberbach and Rockman, 2006; Svara, 1999; Farazmand, 1997; Narduli and Stonecash, 1981). A pervasive argument has been the 'dual roles' approach, which recognises distinct roles in the political administrative process, and has framed the debate around interacting roles and 
relationships between politicians and bureaucrats with bureaucrats as integral parts of the policy process and governance in general (Aberbach and Rockman, 2006; Svara, 1999; Farazmand, 1997; Narduli and Stonecash, 1981). Other studies have found the 'overlapping roles' model dominant in practice, senior officials overlapping with elected officials in policy making. Much of the research shows overlapping roles rather than separate roles to be the norm (Svara, 2006; Mouritzen and Svara, 2002).

Much of the research in this area is often focused on the senior civil service (e.g. Permanent Secretaries) and their political masters (e.g. Ministers). Seldom are there studies which explore the political administrative interface at other levels of governance, in particular local government. Although there is much research on legislative, constitutional and political change, and similarly research on administrative reforms and modernization of local government (Copus, 2006; 2004; Leach, 2006; Morrell and Hartley, 2006; Rao, 2005; Leach and Copus, 2004; Lowndes and Leach, 2004; McAteer and Orr, 2003; Stoker et al, 2003; Leach and Wilson, 2002; Temple, 1996), there are few studies which explore the effects of political change on administrative aspects of local government (Leach and Lowndes, 2007; Liddle, 2007; Fenwick et al, 2006; Leach and Charteris, 2000; Rallings et al, 1995). Certainly in the UK, it is considered an often neglected area of study (Wilson and Game, 2006). The considerable body of work which does exist is US based (Svara, 2006; 1999; 1985; Frederickson et al, 2004; Nalbandian, 1999; Golembiewski and Gabris, 1994) and emerging work from Scandinavia (Jacobsen, 2006). While notable comparative work exists, this is focused on setting out a typology of political administrative configurations contingent on different forms of (western) democratic governance (Mouritzen and Svara, 2002).

There are two broad (distinct but complementary) bodies of work on the relationship between elected members and senior officials in councils. First, that resulting from changes in governance structures in English local authorities occasioned by a political change. The Local Government Act of 2000 aimed at strengthening leadership and decision making through executive style structures of governance (for instance, cabinet-executive systems). Research and evaluation of this change has been carried out including analyses of differences in status between executive cabinet members 
and non executive council members (Rao, 2005), policy and scrutiny role of councilors (Greasley et al, 2004), satisfaction of elected members with these arrangements (e.g. John and Gains, 2005).

Second, there is key research on the political administrative interface more generally. In the English and Welsh setting the key piece of work on the political bureaucratic relationship by Leach and Lowndes' (2007), based on nine English and Welsh local authorities, found that there are a number of roles performed by administrative leadership in local councils (no similar research has been undertaken in Scotland; this paper starts to address that gap). Their research showed the Wilsonian dichotomous tradition of a split between politicians and officers, i.e. councillors make policy and officers implement the policies, to be an over-simplification (ibid). Chief executives provide strategic direction by leading corporate strategy in less politicised local authorities while in more politicised councils it was common practice for the majority party manifesto to form the basis for the council's strategy (Leach and Lowndes, 2007). This paper complements those bodies of work by analyzing the impact of electoral change (the move to single transferable voting, STV, in 2007 for Scottish council elections) on political bureaucratic relationships.

\section{Policy and Political Change in Scottish Local Government}

The Local Governance (Scotland) Act 2004 legislated for STV and multi member wards for local authority elections in Scotland from 2007. STV and multi member wards were not new to Scotland. STV was used to elect education authorities from 1909 until 1928 when local councils assumed responsibility; Stirling Council has used STV to elect its community council; prior to 1975 multi member wards were used to elect Scottish local councils, with elections held annually in cities and burghs for one third of councillors and every three years in counties and districts (Wheatley, 1975). Currently multi member constituencies are used in elections to councils in parts of England and Wales although the winners are determined by plurality (Thrasher et al, 2000). 
However, the motivation behind the 2004 Act can be traced to the McIntosh Commission's (1999) 'urgent' recommendation to study (with a view to early legislation) the electoral system for local government. This led to the Scottish Executive's establishment of the Reviewing Local Democracy Working Group chaired by Richard Kerley, which recommended the STV electoral system (Kerley, 2000). Importantly the legislation which enacted this was part of the coalition negotiation between Labour and Liberal Democrats, necessary to keep this coalition in power following the 2003 Scottish parliamentary elections (Denver and Bochel, 2007). The impetus to introduce electoral reforms was to enhance democracy at local government level (Kerley, 2000).

The STV system adopted in Scotland, like other STV systems, allowed voters to indicate an order of preference for candidates on the ballot, ranking as many candidates as desired. Candidates are successful when an electoral quota is achieved (number of valid votes cast / number of seats to be filled +1 ). Therefore if there are three seats to be filled, the quota is a quarter of the valid votes cast plus one. If fewer than necessary candidates achieve the quota, then there is a transfer of votes: in the first instance, surplus votes from a winning candidate are transferred according to the second and subsequent preferences of voters; if necessary the bottom placed candidate is eliminated and his / her votes are re-distributed. This process continues until the required numbers of candidates achieve the quota (Bennie, 2007; Bennie and Clark, 2008; Gilmour, 2007).

\section{Political Changes: STV and Multi Membership Wards}

At the 2007 local elections in Scotland, STV was used to elect over 1200 local government councillors on the basis of electoral wards, consisting of three or four councillors. This led to a more proportional distribution of seats on councils, reflecting more proportionately the distribution of votes cast for each party than the previous first past the post system, which disproportionately favoured the Labour Party. The result of this electoral reform was a greater proportionality in terms of a closeness of match between votes cast for a party and the overall council representation of that party. There were two related outcomes. First, due to the 
creation of multi member wards, instead of the pre 2007 single member representative first past the post wards, there are now 353 new wards, one quarter of the previous number: 163 with four councillors and 190 with three, most wards having mixed party representation. Second, there has been an increase in the number of councils with no overall party control. Table 1 illustrates the turnaround of political control in Scottish Local Government from 2003 - 2007.

[Insert Table 1 here]

This paper provides a preliminary analysis of the impact of this electoral change on aspects of the political administrative/bureaucratic interface in local government in particular chief executives of councils. There are four broad areas examined, expressed as propositions.

First, as anticipated, there is a contrast with pre 2007 in that there is a far greater propensity towards councils having a greater diversity of representation - that defined in contrast to the comparative uniformity of single party majority control. This change is most marked in central Scotland. The research explores the impact of the STV induced change on the general broad political bureaucratic role of chief executives.

Leach and Lowndes (2007) research in England and Wales indicated that chief executives' roles were to ensure good performance of local authorities, but senior officers had to display a level of political awareness by acting as an 'early warning' system, notifying the political leadership of operational problems (e.g. budget overspends) to prevent political embarrassment and liabilities (ibid). The role of providing a stable decision making environment was particularly tested when there was no overall majority council and informal rules may come into play such as chief executives acting as intermediaries between political parties or deflecting adversarial politics in council meetings (ibid). Thus, their research showed a more active engagement of chief executives in the political environment by mediating political interests of elected members especially in no overall majority councils (ibid). Our first proposition is that where there is no overall majority in Scottish local government 
as a result of the electoral and political changes, there would be more active political management by chief executives.

Second, it can be argued that the lack of overall control, added to the multi party representation in many wards leads to a lessening of policy coherence and slower policy/decision making. Studies from Pressman and Wildavsky $(1973 ; 1984)$ to more recent work indicate that increasing the layers and linkages (vertical, horizontal and organizational) amongst policy actors increases the complexity of the policy process (e.g. Hupe and Hill, 2006; Scharpf, 1997). Yet some initial case study work has indicated that the introduction of STV in Scottish council elections and the consequent loss of overall party control has not led to lack of policy direction or to inefficient decision making (Electoral Reform Society, 2010). Thus, our second proposition is that no overall majority in councils does not lead to a lack of policy coherence and slow policy/decision making.

Third, it can be suggested that there may be greater scrutiny of policy making after the introduction of STV, particularly where previously one party has traditionally dominated disproportionately, this skewing the activity of council officers towards servicing the dominant party at the expense of other parties in the council, or the council as a whole. Accompanying this, it could also be argued that the requirement to service and advise three or four councillors per ward representing different parties will lead to job and role extension. Early case research indicates increased levels of scrutiny of political decisions by elected members within councils (Electoral Reform Society, 2010), though there has been little directly stated on how this affects senior officials. Our third proposition is that the electoral and political changes have resulted in an increased level of scrutiny in policy making.

Fourth, is the area of democratic enhancement. The electoral reform was introduced on the premise of 'renewal of local democracy' (Kerley, 2000), achieved partly via increased proportionality in the system. It was always understood that a trade off was required between proportionality and the maintenance of a councillor ward link: the greater the number of seats per ward the more proportionate the result is likely to be, but increased numbers of representatives per ward comes at the expense of the 6 
councillor ward link which potentially brings a dilution in the public's perception of the representative - ward accountability relationship. This leads to the possibility of unpredictable constituent behaviour. Who does a constituent contact in a ward with several representatives? Additionally, how do ward representatives especially in the context of multi party ward representation, relate to each other? A balance was struck between proportionality and the desire to maintain the councillor ward link in the proposed (Kerley, 2000) and actual legislation. This balance could be a tension point facing chief executives and other senior officials in their political administrative/ bureaucratic roles. Thus, our fourth proposition is that there are tensions for chief executives in balancing demands emanating from multi ward representation and democratic accountability or responsiveness.

\section{Research Method}

The research sought to explore the propositions and involved primary and secondary data collection and analysis. The secondary data included scholarly literature, government reports and policy documents, as well as data sourced from government websites. The primary data collection methods involved qualitative self-report questionnaires and interviews of senior officers within Scottish local authorities. The optional choice of an interview or self-report questionnaire was given to participants in order to improve response rates. The survey instrument for the interviews and selfreport questionnaires was standardized. The survey focused on the role and responsibilities of the administrative leadership within local government; the impact of multi membership wards; the effect of STV. To ensure robustness the survey instrument was piloted with seven focus groups of senior to middle managers $(n=93)$ from three local authorities. The three local authorities approximated a cross section of the post 2007 election environment. These local authorities experienced a changed political complexion with two having no overall party in control. One covered a mainly rural area and two covered mixed rural-urban areas with significant urban population concentrations, yet sizeable rural hinterlands. The focus groups informed the design of the survey instrument. All chief executives of Scotland's thirty-two local authorities were approached to participate in the research. The response rate was 
forty-six percent $(n=15)$. For ethical assurances of anonymity and confidentiality, the reported findings and quotations are anonymized.

\section{Findings}

\section{Proposition One: Political Management}

STV has increased the likelihood of no overall majority councils or political parties working in coalition to form a governing body/ an administration. These political configurations are often fragile with a reliance on cross-party working or dependence on independent councillors to reach a consensus in decision making. It has resulted in an increased level of coalition and minority administration politics. There was an overall consensus in responses that coalition and no overall majority administrations have increased the complexity of chief executives' roles. Chief executives stated their level of political awareness and engagement with all political parties has increased. In previous administrations there would have been a stronger presence of engagement and work with one political party which formed the majority administration. Prior to 2007 in over $40 \%$ of councils, the Labour Party had the overall majority (with the figure higher in central belt councils). Throughout Scotland two thirds of all councils were single party controlled - Labour 13 councils, Independent 6 councils, Lib Dem or SNP with 1 council each. Since 2007 minority or coalition administrations are the norm (27 of the 32 councils - see Table 1$)$.

The research found an increase in chief executives' level of political engagement and required acumen. For example two chief executives saw a change in administration within one year when the coalition administration dissolved and thereby necessitated working with new administrations. The following quote illustrates the increased complexity of the chief executives' roles within no overall majority councils:

'In the past the majority of chief executives, we are responsible for delivering the policies and priorities of the council, and in the past this would happen through a political party which would have the majority of seats so you had a single relationship with the administration at the time and that meant that you 
could have that dialogue. You could sit down in a room, you could actually debate the ins and outs of things, of different things and could decide what is going to be recommended and it then goes in front of the Council but you know in taking something forward you know it has been debated and you know you have got the agreement of the administration of the political party in power. That no longer is guaranteed by any means. So the role of a chief executive is now that you are not dealing with one political party, but now when you have new policies coming through you now have to square the circle and deal with all the political parties because decisions could go in any direction.' (CE C)

'In terms of leadership post-election, there is now a different dynamic to member - officer relationships...The need to manage more complex political relationships has a day-to-day impact on the chief executive's leadership role with regard to the fact that all of the wards within this authority are 'split wards', and the relationship between the representatives of each of the wards, as well as between the parties and also between members and officers has to be dealt with sensitively, firmly and in an egalitarian manner' (CE D).

\section{Proposition Two: Policy Coherence}

A related point to increased political management by chief executives is, as the above quotes reveal, a level of unpredictability in decision making and voting outcomes of councils. There was a consistent finding of a lack of coherence from the political leadership. Chief executives stated that their political management role has increased in an attempt to reach a consensus across the political leadership and the council. Chief executives stated that no overall majority and coalition politics have resulted in less policy direction from the political leadership. The lack of consistent policy direction and often constant changes to policies from the political leadership has increased their job demands and respondents believed that the lack of direction has impacted negatively on improving service delivery at a local level. Yet, chief executives believed that a positive outcome of no overall majority and coalition administrations was the opportunity to build consensus and increase the 
representation of the diverse interests in policy. But chief executives also felt that this led to 'satisficing' rather than optimal decisions being made. According to one chief executive there is less opportunity for positive and dynamic change, but rather more time spent on consensus building and satisfying all political interests, often resulting in slow, incremental change. A frustration expressed by many chief executives was the slow pace of decision making - a result of consensus politicking. Chief executives stated that the most demanding aspect to their increased political management role is attempting to achieve a consensus among political parties in order to ensure coherence and a clear policy direction from political leadership. Some chief executives defined their political management role as 'honest brokers' in a political game often requiring good negotiation and conflict resolution skills. The following quotes illustrate this point:

'It has certainly made our leadership much more sharp and clearly defined because we are constantly trying to move between the administration and the other people surrounding the administration whether it is the main opposition or the independents or the other minor parties because they have to come forward with ways in which to work together and the chief executive then takes on a much stronger role in having to sort of manage that process. So it is a situation where a chief executive has to get to be more fleet-afoot and produce even a more stronger leadership for the Council because they have to work across so many different groupings and arrangements' (CE E).

'So you are actually in a position at the moment where political coherence is a lot less apparent than it used to be. In another forum I would argue that is not a bad thing but actually when you are trying to deliver services on the back of it creates time delays and confusion. I have no difficulty with them doing the politics except when it gets in the way of making progress. To be honest I don't think any of these issues were properly thought through by people who legislated .... I hate to compare the role of a chief executive to a stressed-out parent but it just seems like it...the role of a chief executive is the management and priorities and part of that is political management and yes part of that is also being a broker between the political parties...' (CE C). 
In terms of politicking within the councils chief executives noted the influential role played by independent councillors in the ability to shift the balance of power within the council. The chief executives noted that this provides independent councillors with considerable leverage, which they draw upon as a source of 'horse-trading', often skewing decision making.

\section{Proposition Three: Scrutiny of Policy Making}

Chief executives noted that there is more interrogation and briefing required with regard to the political leadership within the council. Thus, the chief executives' level and intensity of policy advice has increased, often requiring chief executives to be much more prepared for questions and discussion around policy. Many respondents viewed this as having positive and negative outcomes. For example, there has been an increase in job demands, but there has also been an improved level of accountability and scrutiny of policy advice. Many of the chief executives with regards to the latter point argued that it has improved policy making. However, a frequently cited negative outcome of both STV and multi member wards was the increase in job demands, which as the quotation below indicates can work to the detriment of substantive policy advice and robust policy making. The research found that multi member wards have increased job demands for chief executives and senior officers. Senior officers have to be responsive to three or four councillors for each ward as opposed to one. For example, a chief executive stated that:

'One of my Directors was saying the other day that he set up a separate email account for all emails coming in from councillors... in the past he and his secretary could actually work that through, but now he has got two administrators working full-time on it and if that is one service area replicate, that among the four services and I would suspect we have actually had to increase the number of staff to cope with this by half a dozen...but my take is that a lot of senior managers in local government are stressed by the additional work they are being asked to do at the moment. More council meetings, more meetings in the evening, non-stop requests for information and certainly the 
debate we have had in my management team is that we are no longer having the time to do the policy, strategy stuff and taking things forward because we are actually caught up in what one of my Directors recently called the "grunge" of multi member wards. It is actually reducing the capacity for local government to be innovative and go forward. So yeah I do think there has been a lot of damage done by multi member wards in that respect. I mean I have got senior officers in my council at the moment not approaching retirement age saying "I am getting out of this I am not doing this, I can't tolerate this any longer."' (CE C).

\section{Proposition Four: Democratic Enhancement and the Role of Chief Executives}

The democratic enhancement which STV and multi member wards in local councils was designed around, represents a trade-off between proportionality on the one hand and the desire to have a councillor ward accountability link on the other. How this impacts on chief executives in their political administrative interface can be viewed in three ways.

First, the research found that rivalry and political trading among ward councillors often increases the level of chief executive and senior officers' political management role. As a chief executive noted:

'We get a lot more pressure from elected members. A lot more complaints. Yes, it's because there are members of different political groups representing a ward. They are all in competition with each other in the ward. We have a very political Council. The bulk of councillors are either Labour or SNP and they are very adversarial to each other. Before that was in the Council but now it spills over to multi member wards. It's mostly personalities' (CE B).

Second, a further outcome of multi member wards is 'game-playing' by constituents. Some constituents who are aware they have a 'choice' among three to four councillors within a ward, often of different political persuasions, pit councillors against each

other or intensify rivalry to maximise the outcome in their favour. Similarly, constituents who are not satisfied with an outcome of an administrative decision seek 
intervention from the various ward councillors until they receive a satisfactory outcome. The conjunction of this 'game playing' by constituents and rivalrous politicking among councillors often increases the workload and job demands for officers as the following quote illustrates:

'Challenges vary from where one member has been approached on an issue by a constituent and raised that issue with officers and been given a response and the response isn't to the satisfaction of the constituent, and will go to another member and that member makes further representation on the same matter. Now with a large organisation the potential for the second referral perhaps not to be dealt with by the same individual and it would be very difficult if another response was given. So ensuring that there is consistency in communication throughout the system is very, very important. I hope that explains just some of the challenges that the multi member ward system represents' (CE G).

Third, respondents noted that a negative outcome of the multi member ward is a democratic deficit. Whilst some constituents understood the new multi member ward system (as noted above), many constituents are neither aware nor understand the system. Some respondents noted that the administration of the council often receive correspondence from constituents with regards to the political representative for their ward having been accustomed to the first past the post system. Respondents are of the opinion that more voter education about the multi member wards and STV is required to address what they referred to as a democratic deficit.

Thus, the responses to questions of whether STV and multi member wards enhance democracy were mixed. There was a clearly articulated view that the balance between the proportionality of multi member wards and accountability was rather uneasy, causing tension for chief executives in their political management role. Some chief executives went as far as to state that STV did not enhance democracy as it created more scope for conflict requiring mediation or brokering by the administrative leadership to ameliorate political tensions. They also believed that STV created a democratic deficit since the dominance of politicking and rivalrous behaviour distracted or deflected real scrutiny and accountability of policy decisions and/or 
often slowed the pace of decision making for service delivery improvements. On the other hand, chief executives believed that STV and multi member wards enhanced democracy as there was more diverse political representation as opposed to one party dominating the political leadership of the council. These chief executives believed that there was a proportionate representation of the local community's interests and with more political representation there was scope for the scrutiny of policy and decision making. Another facet which some chief executives expressed was a degree of uncertainty as to whether STV and multi member wards enhanced democracy as they recognised the diversity of political representation, yet acknowledged the lack of stable government undermined policy making and service delivery. In addition there was an acknowledgement of the level of voter unawareness of the system, a lack of clarity about which councillor represented constituent interests and which elected representative to hold accountable for matters occurring in the ward.

In terms of the first research proposition there is evidence that where there is no overall majority councils (the majority of cases in Scotland), chief executives play a more active political management role in their respective local councils. This finding is consistent with the English and Welsh local government study (see Leach and Lowndes, 2007). Second, the research suggests that indeed where there is no overall majority council, there is a lack of policy coherence and slow policy/ decision making. This finding is inconsistent with the Electoral Reform Society (2010) research. The third proposition: the electoral and political changes in Scottish local government has led to an increase in scrutiny in the policy making process and consequent increase in job demands of chief executives. Finally, although there is no conclusive evidence whether the electoral and political changes have indeed enhanced democracy, there are tensions for chief executives and senior officers in balancing the demands of responsiveness and accountability with consequent increased job demands.

\section{Conclusion and Future Research Directions}

The research indicated there is clearly more active engagement in political management by chief executives in the post 2007 environment. Nonetheless, the 
relationship between chief executives' administrative sphere and the political sphere indicated the existence of boundaries: there was no sense in which one dominated the other or that there was competition between spheres in the political process (Svara, 2006). In other words this research found the existence of overlapping - consistent with other scholarly writing in this area.

Other related evidence lends support to the findings of Leach and Lowndes' (2007). Scottish chief executives view their role as providing advice for the council to set policy direction; providing a stable decision and policy making environment through their political management role. According to Leach and Lowndes (ibid) in no overall majority councils the stable decision making environment was tested, providing chief executives with more scope in developing policy. Similarly our research found that chief executives within no overall majority councils, given the relative absence of strong political leadership or direction, have more scope to provide advice for policy direction for the council. The increased level of chief executives' political management arguably is a shift from the traditional role of being merely head of paid service and towards a bureaucratisation of political and policy roles. Some chief executives noted advantages in this changed environment: the lack of no overall majority led to the requirement for consensus building and greater degrees of political inclusion in decision making.

Some chief executives noted that STV and the resultant no overall majority councils have brought some disadvantage resulting in a decline in policy direction with adverse implications for the effective delivery of service. For example, consensus building often led to the slow pace of decision making and the 'satisficing' of decisions with less scope for innovative change and service delivery. Such a decline in policy coherence and direction may be accounted for, if projected Scotland wide, by two other aspects of the change in the electoral system. First, there was a substantial 'churn' of councillors in the newly elected local councils in 2007 due to the more proportional distribution of seats plus the fewer than usual incumbents choosing to defend their seats: in $200376 \%$ of those who won council seats were already incumbents, but in 2007 the figure was only 51\% (Denver and Bochel, 2007). Second, in 7 councils overall, the administration excluded the largest party from 
office (Bennie and Clark, 2008). Arguably both these factors may reflect, in the first instance, a relative lack of experience in council policy making capacity amongst councillors and, in the second, exclusion of policy capacity from the largest party group elected to the council. This may explain the inconsistency of findings between this study and the Electoral Reform Society (2010) research. Thus, further research concerning political change and the impact on policy coherence is required.

It appears that the changed political landscape has increased the level of chief executives' role in the political administrative interface; in terms of increased job and role demands the evidence was uniform. There are also examples of increased responsiveness and accountability upwards to political leadership through more scrutiny of policy advice. This was consistent with other research undertaken in a number of councils where it was shown that senior officers took a much more proactive role in providing advice and support to all major political parties, including those in opposition, to an extent 'unthinkable' pre 2007 - with clear outcomes on the quality of policy scrutiny (Electoral Reform Society 2010). Chief executives suffer from role stretch with the enlarging political management role and the responsibilities of ensuring consensus and mediating various political interests, responding to councillor/ constituency demands, increased policy advice and scrutiny. This has consequently increased the chief executive's role as key in the political environment nexus. Thus, there was considerable tension and chief executive role stretch caused by the changes to the democratic configuration of council representation. The research showed that no overall majority in conjunction with multi member wards created considerable role stretch, the resultant political rivalry among councillors requiring brokering by chief executives in order to build consensus and enable a stable decision making environment to achieve consistent direction from the political leadership.

Voter awareness of STV and multi member wards represents a significant democratic deficiency as well as increased demands on the chief executive role, although the level of constituency 'game-playing' may indeed add value to democratic ideals by increasing the level of chief executives' responsiveness and accountability downwards towards constituents and external clientele. 
Finally there are areas which could form a research agenda to build on the work undertaken for this paper. First, there is need for a longitudinal study on the effects of future elections on administrative leadership to provide a more comprehensive study. The campaigning period prior and during the elections will see an increase in political rivalries. As one respondent noted:

'...what happens in the next election? How do they compete against each other? Because previously all opposition parties campaigned against Labour but now that they are in power how will they work in a campaign environment? They will have to compete against each other. How will this affect council working e.g. committee working? In the lead up to the election which will probably be from January 2012 they will have to start campaigning and that is when rivalries will start'.

The political rivalry during the election period will affect multi member ward working, strategic direction from political leadership, a stable decision and policy making environment. This will increase the chief executive's political management role - the likelihood is the increased bureaucratisation of political and policy roles, with chief executives addressing the void in policy direction due to politicians being pre-occupied with electioneering. On a wider canvas, the true extent of the bureaucratisation of political and policy roles within local government and tensions within the political administrative interface throughout the UK deserves further investigation. Whether the medium-longer term outcome of local government modernisation and change initiatives is an evolution of political administrative relations towards 'strong leadership', or whether it entrenches tensions and increases the scope for bureaucratisation of political and policy roles, requires a longitudinal study across UK local government.

Second, the research can be deepened beyond the impact of electoral process. There is evidence to suggest that the political changes thus far at Scottish local government level have enabled chief executives to have more scope of influence in the political realm and policy process, principally to ensure a policy/ decision making and service delivery environment. Research is required on a range of contingent factors which 
may influence the precise nature of political management arrangements. For instance, the form of internal governance used (cabinet, traditional committee, executive and corporate management, etc). Also, notwithstanding 'overlapping' and 'dual roles' approaches, politicians and bureaucrats do inhabit different spheres and roles in the political administrative system (Egberg, 1995) and bureaucrats will likely take a more detached view when reconciling political demands, balancing different political wishes and interests with financial realities: the constrained financial climate in the forthcoming period may well be an important contingent factor when analyzing political bureaucratic relationships.

A final research area, following naturally from the focus of this paper, is to increase the scope of the political bureaucratic interface research field: to include other local council officers below the most senior (e.g. those working at neighbourhood or area management level); and to analyse and scrutinize relationships with quasi representative organizations (like community groups, citizens' fora, etc). Indeed the research has accentuated relevance given the 'political' role played by UK senior civil servants in brokering the Conservative-Liberal Democrat coalition government in May 2010 (Blitz, 2010), as well as the possible outcomes of political administrative relations given the forthcoming debate on electoral reform at Westminster.

\section{References}

Aberbach, J.D., Putnam R.D. and Rockman, B.A. (1981) Bureaucrats and Politicians Western Democracies, Boston, MA. Harvard University Press.

Aberbach, J.D. and Rockman, B.A. (2006) 'The past and future of political-administrative relations: research from bureaucrats and politicians to In the Web of Politics - and beyond', International Journal of Public Administration, 29:1 pp. 977-955.

Bennie, L. (2007), STV in Scotland: Local Government Elections 2007, paper presented at Political Studies Association Conference, University of Bath 11-13 April 2007.

Bennie, L. (2006), 'Transition to STV: Scottish local government elections 2007' Representation 42 (4) pp273-287.

Bennie, L. and Clark, A. (2008), 'The transformation of local politics? STV and the 2007 Scottish local government elections', Representation 44 (3) pp225-238.

Blitz, J. (2010), Financial Times, 15 May 2010. 
Clark, A. and Bennie, L. (2008), 'Strategic actors or muddling through? Political parties, local campaigning and the single transferable vote', Representation, 44 (4), pp. 327-340.

Copus, C. (2006), 'British local government: a case for a new constitutional settlement', Public Policy and Administration, 21 (2), pp. 4-21.

Copus, C. (2004), Party Politics and Local Government, Manchester. Manchester University Press.

Denver, D. and Bochel, H. (2007), 'A quiet revolution: STV and the Scottish council elections of 2007', Scottish Affairs 61 pp1-17.

Egberg, M. (1995), 'Bureaucrats as public policy-makers and their self interests', Journal of Theoretical Politics 7 (2) pp. 157-167.

Elcock, H. (2006), 'Local political leadership in Britain: rake's progress or search for the holy grail?, Public Policy and Administration, 21 (2), pp. 22-37.

Electoral Reform Society (2010), Working with STV: An Electoral Reform Society Report for Parties and Councilors, Glasgow / London: Electoral Reform Society.

Farazmand, A. (1997) Introduction, in Farazmand, A. (ed), Modern Systems of Government Exploring the Role of Bureaucrats and Politicians, London. Sage.

Fenwick, J., Elcock, H. and McMillan, J. (2006), 'Leadership and management in UK local government: a role for elected mayors?' International Review for Administrative Sciences, 72 (3), pp. 431-447.

Frederickson, H.G., Wood, G.A. and Wood, C.H. (2004), The Adapted City: Institutional Dynamics and Structural Change, M.S Sharpe Inc.

Gains, F. (2004), 'The Local Bureaucrat: A Block to Reform or a Key to Unlocking Change?', in Stoker, G. and Wilson, D. (eds.) British Local Government into the $21^{\text {st }}$ Century, London. Palgrave Macmillan.

Gilmour, J. (2007), 'Detailed description of the STV count in accordance with the rules at the Scottish Local Government Elections Order 2007', Representation 43 (3) pp217-229.

Golembiewski, R.T. and G. Gabris, G. (1994), 'Today's city managers: a legacy of successbecoming failure', Public Administration Review, 54 pp. 525-537.

Green, D. (1981), Power and Party in an English City, Allen and Unwin.

Greasley, S., Gains, F and Stoker, G. (2004) 'Local Political Management: a progress report after two years' New Economy, 2004, 11 (2).

Gyford, J., Leach, S. and Game, C. (1989), The Changing Politics of Local Government, Allen and Unwin.

Hupe, P.L. and Hill, M.J. (2006), The Three Action Levels of Governance: Re-framing the Policy Process Beyond the Stages Model, in Peter, B.G. and Pierre, J (eds) Handbook of Public Policy, London: Sage. 
Jacobsen, D.I. (2006), 'Public sector growth: comparing politicians' and administrators' spending preferences', Public Administration, 84 (1) pp. 185-204.

John, P. and Gains, F. (2005), Political Leadership Under the New Political Management Structures, Office of the Deputy Prime Minister.

Kerley Report (2000), Report of the Renewing Local Democracy Working Group, Edinburgh: HMSO

Laffin, M. and Young, K. (1985), 'The changing roles and responsibilities of local authority chief officers', Public Administration, 63 (1), pp 41-59.

Leach, S. (2006) The Changing Role of Local Politics in Britain, Bristol. Policy Press .

Leach, S. and Charteris, S. (2000) 'Managing the budgetary process in a hung council', Public Administration, 78 (4), pp. 793-814.

Leach, S. and Copus, C. (2004) 'Scrutiny and the political party group in UK local government: new models of behaviour', Public Administration, 82 (2), pp. 331-354.

Leach, S. and Lowndes, V. (2007) 'Of roles and rules: analysing the changing relationship between political leaders and chief executives in local government', Public Policy and Administration, 22 (2), pp. 183-200.

Leach, S. and Wilson, D. (2002), 'Rethinking local political leadership', Public Administration, 80 (4), pp. 665-689.

Liddle, J. (2007), 'Challenges to democratic legitimacy, scrutiny, accountability in the UK national and local state', Public Administration Quarterly, Winter, pp. 397- 428.

Lowndes, V. and Leach, S. (2004) 'Understanding local political leadership: constitutions, contexts and capabilities', Local Government Studies 30 (4), pp. 557-575.

McAteer, M. and Orr, K. (2003), 'The 'modernisation' of political management arrangements in post devolution Scottish local government', Public Policy and Administration, 18 (1), pp. 63-83.

McIntosh Commission. (1999) Moving Forward: Local Government and the Scottish Parliament, Stationery Office.

Ministry of Justice. (2007), The Governance of Britain, Cm 7170, HMSO.

Morrell, K. and Hartley, J. (2006) 'A model of political leadership', Human Relations, 59 (4), pp. 483-504.

Mouritzen, P.E and Svara, J.H. (2002), Leadership at the Apex: Politicians and Administrators in Western Local Governments, Pittsburgh, PA. University of Pittsburgh Press.

Nalbandian, J. (1999), 'Facilitating community, enabling democracy: new roles for local government managers', Public Administration Review , 59 pp. 187-197.

Nardulli, R.F. and Stonecash, J.M (1981) Politics, Professionalism and Urban Services, New York. Oelgeschlager, Gunn and Hain Publishers. 
Pressman, J. and Wildavsky, A. (1973/1984), Implementation: How Great Expectations in Washington are Dashed in Oakland; Or, Why It's Amazing that Federal Aid Programs Work at all, This Being a Saga of the Economic Development Administration as Told us by Two Sympathetic Observers who Seek to Build Morals on a Foundation of Ruined Hopes, Berkeley: University of California Press.

Rallings, C., Temple, M. and Thrasher, M. (1995), 'Coalitions in Britain: administrative formation in hung councils', Policy and Politics, 23 (3) pp. 223-232.

Rao, N. (2005) Councillors and the New Council Constitutions, ODPM

Saunders, P. (1980), Urban Politics: A Sociological Interpretation, London. Penguin.

Scharpf, F.W. (1997), Games Real Actors Play: Actor Centered Institutionalism in Policy Research, Boulder CO: Westview Press.

Stewart, J. (2003), Modernising British Local Government, London. Palgrave MacMillan.

Stewart, J. (2000), The Nature of British Local Government, London. MacMillan.

Stoker, G., Gains, F., John, P., Roa, N. and Harding, A. (2003), Implementing the 2000 Act with Respect to New Council Constitutions and the Ethical Framework: First Report, ODPM.

Svara, J.H. (2006) 'The search for meaning in political-administrative relations in local government'. International Journal of Public Administration, 29: pp. 1065-1090.

Svara, J.H. (1999) 'Complementarity of politics and administration as a legitimate alternative to the dichotomy model', Administration and Society, 30:6 pp. 676-705.

Svara, J.H. (1985), 'Dichotomy and duality: re-conceptualising the relationship between policy and administration in council-manager cities', Public Administration Review, 45: pp. 221-232.

Temple, M. (1992), 'Seeking and sharing office in hung English councils', Public Money and Management, 12 (2) pp. 35-39.

Thrasher, M., Rallings, C. and Stoker, G. (2000) Electoral Reform in Local Government, Joseph Rowntree Foundation.

Wheatley Report (1969), Royal Commission on Local Government in Scotland, Edinburgh: HMSO.

Wilson, D. and Game, C. (2006), Local Government in the United Kingdom $4^{\text {th }}$ edition, London. Palgrave Macmillan. 
Table 1: Political Control of Councils 2003 - 2007 Scottish Local Authority Elections

\begin{tabular}{|l|c|c|}
\hline Political Control & $\begin{array}{c}\text { Number of } \\
\text { Councils 2003 }\end{array}$ & $\begin{array}{c}\text { Number of } \\
\text { Councils 2007 }\end{array}$ \\
\hline Single party or group control: Labour & 13 & 2 \\
\hline Single party or group control: Independent & 6 & 3 \\
\hline Single party or group control: Lib Dem & 1 & 0 \\
\hline Single party or group control: SNP & 1 & 5 \\
\hline Total single party or group control & 21 & 27 \\
\hline No one party or group control & 11 & 32 \\
\hline Total number of councils & 32 & 0 \\
\hline
\end{tabular}

